\title{
Guden der steg ned fra himlen \\ - Niels Bukh, national identitet og politik
}

Af Hans Bonde

»Niels Bukh er i dag for den danske landbobefolkning meget nær det samme, som Grundtvig var i sin mest livskraftige periode $\ll$.

Dagens Nyheder ${ }^{1}$.

Den danske gymnastikpædagog Niels Bukh var som Kaj Munk og Arne Sørensen blandt de store højreradikale danskere, som i 1930'rne ikke følte sig repræsenteret i det danske partisystem, ja i det hele taget afviste det parlamentariske system. Han tog også afstand fra det danske nazistparti, fordi det både organisatorisk og ideologisk var en kopi af det tyske moderparti. Bukh vil i det følgende blive set som et eksempel på, hvor accepteret højreradikale holdninger kunne være i den danske offentlighed. Populært sagt kunne man i 1930'rne godt både blive anset for stærkt national og stærkt antidemokratisk endog med en faible for nazismen.

Niels Bukh, hans elever og hans gymnastik havde rødder i den danske gårdmandsklassse. I modsætning til mange andre europæiske lande lykkedes det for de danske gårdmænd at opnå selveje, hvilket dannede baggrund for, at de fik stor indflydelse på udformningen af det moderne danske samfund. I slutningen af 1870'rne var det danske landbrug kommet ind i en afsætningskrise. Svaret på denne udfordring blev andelsbevægelsen, som bredte sig til hele landbrugssektoren i stort set samme takt som bønderne begyndte at dyrke den såkaldte lingske ${ }^{2}$ eller svenske gymnastik i deres forsamlingshuse og på $h ø j-$ skolerne. Betoningen af fællesskabet foregik både i andelsbevægelsen og i gymnastikken.

Den lingske gymnastik kan ses som den kropslige dimension i den grundtvigianske vækkelse, hvor den skinnende, hvidklædte gymnast, som rankede sig, så lyset kunne falde på ham, blev et symbol på de myndige bønder, som var i færd med at forvandle sig fra almue til folk, og som frem til århundredskiftet kæmpede for politisk demokrati. Med den $\varnothing$ konomiske verdensdepression og det danske landbrugs krise $\mathrm{i}$ 1930'rne blev gårdmændenes forhold til det demokrati, som bla. havde bragt den nye store samfundsklasse arbejderklassen og dets parti Socialdemokratiet til magten, mere ambivalent, og i denne højredrejning af det danske landbosamfund indgik Niels Bukh markant.

Niels Bukh medvirkede til den revolutionering af den lingske gymnastik, som fandt sted i flere europæiske lande efter århundredskiftet, og som rummede et opgør med den stive, opstykkede eksercitsgymnastik. Det nye hos Niels Bukh var betoningen af rytmen og lange serier af $\varnothing v e l-$ ser uden ophold undervejs. Niels Bukhs såkaldte »primitive gymnastik « fastholdt landgymnastikkens kollektive element, men søgte gennem meget hårdhændede og 
konditionskrævende stræk $\varnothing v e l s e r$ at opbl $\varnothing$ de de ofte, af det hårde arbejde, stivnede og krummede landboeres kroppe for at gennemføre projektet med at ranke de krumme bønder.

Bukh blev i løbet af 1930'rne sandsynligvis den bedst kendte dansker i udlandet. Han deltog fra 1912 i alle olympiske lege bortset fra Los Angeles 1932 og London 1948 - og var fast inventar ved verdensudstillingerne. Allerede i 1920'rne havde han gjort reklame for Danmark ved hver sommer at rejse til forskellige europæiske lande og i 1923 og 1926 til USA. Kulminationen på hans berømmelse blev »jordomrejsen « i 1931, som bl.a. medførte, at hans gymnastik blev stærkt udbredt i Japan, hvilket kan spores den dag i dag. I resten af 1930'rne fortsatte han sin rejseaktivitet med uformindsket kraft herunder turen til to nye kontinenter Sydamerika i 1938 og Sydafrika i 1939. Overalt hvor Bukh kom, var han med til at genoplive erindringen om fædrelandet hos de titusindevis af udvandrere, som fulgte hans opvisninger. I den danske udenrigstjeneste kan der spores en klar fornemmelse for Bukhs betydning for udbredelsen af kendskabet til Danmark.

Bukh blev for Danmark et ansigt både udadtil og indadtil. Han fremviste sin version af den vesterlandske civiliserede krop for mange hundrede tusinde unge mennesker rundt om i verden på et tidspunkt, hvor dette projekt endnu ikke i større grad blev båret frem af det nye massemedium filmen.

Bukh skabte billeder på danskheden, som kunne fæstne sig i erindringen, uanset om det var »seks mand på plinten«, eller unge landboere som udførte formfuldendte, synkrone bevægelser. Hans nationale symbolværdi blev forstærket ved, at hans gymnastik til forskel fra f.eks. det danske fodboldlandshold blev kendt som et originalt produkt i dansk kropsdesign. Kongen optrådte allerede så tidligt som i 1923 ved indvielsen af Bukhs stadion og dekorerede ham flere gange personligt, senest i 1935.

Artiklen forsøger at belyse forholdet mellem idræt og dansk national identitet, idet dens hovedperson Niels Bukh, til forskel fra ledelsen af Dansk Idrætsforbund (DIF), ${ }^{3}$ havde et meget stærkt nationalistisk forhold til idræt. Bukhs gymnastik er et eksempel på, hvor stærk en rolle idrætten kan spille i nationaldyrkelsen. Med ham blev forbindelsen mellem gymnastik og danskhed for alvor løftet op på et nationalt plan.

Som parallel hertil kan anføres et par andre biografisk orienterede unders $\varnothing$ gelser af to centrale emotionelle formgivere af dansk national identitet, Niels Martin Jensens om Niels W. Gades nationalromantiske tone og Flemming Lundgren-Nielsens om Grundtvig, som Bukh i højstemte øjeblikke blev sammenlignet med. ${ }^{4}$ Når idræt, musik, sang og »det levende ord « spiller en så central rolle i nationaldyrkelsen, skyldes det, at denne ikke primært formes gennem rationelle overvejelser, men gennem medrivende og samlende emotionelle handlinger.

Det særegne ved idræt i forhold til musik og højskoleforedrag er, at den bygger på følelser af identifikation, spænding og et håb om forløsning, som primært opleves via kropslige handlinger, men også gennem sange, billeder og fortællinger.

Fra århundredskiftet og frem er idrætten blevet en central arena, hvor de enkelte lande kan måle sig med hinanden i stærke symbolske konflikter, og hvor dyrkelsen af det nationale gestaltes rituelt. ${ }^{5}$ Det er i den moderne tidsalder kun ved kongebesøg, i kirken eller ved store idrætsbegivenheder, at mennesker rejser sig i respekt for noget, de føler er større end dem selv. 
Bukh og gymnastikkens betydning for national identitet i Danmark var ikke et isoleret fænomen, men kan f.eks. sammenlignes med Fridtjof Nansens og skiidrættens betydning for norsk national identitet. ${ }^{6}$ Der var også i Danmark i mellemkrigstiden andre nationale samlingsfigurer indenfor idrætten end Bukh og hans gymnastik. Fodboldlandsholdet var dog i udpræget grad et fænomen, som dyrkedes i byerne. Dertil kom de mere bredt appellerende »svømmepiger«, som Jenny Kammersgaard og Lilli Andersen, ikke kun vakte beundring gennem rekorder og medaljer f.eks. ved OL i 1936 i Berlin, men også ved »mentalt $\ll$ at binde den marine nation Danmark sammen gennem svømning over bælt, sund og stræder. ${ }^{7}$

Den britiske idræts- og socialhistoriker J.A. Mangan har opregnet 3 forbindelser, hvor idræt indgår som et middel: 1) til national solidaritet, 2) ved international konfrontation og 3) ved internationalt samarbejde og forståelse. ${ }^{8}$ Som det vil vise sig, udfoldedes Bukhs gymnastik på alle tre niveauer samt på et fjerde: Idræt som en scene for national konfrontation.

Med udviklingen af hans eget gymnastiske koncept havde Bukh fra omkring 1920 påbegyndt afhægtningen af det gymnastiske tegn fra skyttesagen og kampen for Sønderjyllands enhed med »Moderlandet «. Hans gymnastik var derfor blevet åben overfor nye tegnfortolkninger. I slutningen af 1920'rne kritiserede han skarpt det danske parti- og pressesystem og tilsluttede sig den korporativistiske ideologi. I 1933 radikaliserede han kraftigt denne opfattelse gennem sin offentlige tilslutning til nazisternes opfattelse af hans gymnastik som repræsenterende noget af det ypperligste $\mathrm{i}$ den ariske race. Derved blev den disciplinerende og kollektivistiske gymnastik, som var indgået $i$ gårdmændenes demokra- tikamp, nu spændt for en politisk radikalt anderledes vogn, hvilket gav den muligheder for at blive tillagt en helt anden symbolfortolkning.

Bukhs forsøgte efter sin nazistiske offensiv i 1933 at genvinde den brede danske offentligheds tillid, en bestræbelse der kulminerede med hans »Nordiske olympiade « i 1935. Var der så meget plads til højreekstreme holdninger i den danske nationaldyrkelse, at Bukh mindre end to år efter sin nazistiske agitation, uden at frasige sig sine synspunkter, kunne generobre placeringen som én af nationens store sønner?

\section{Optakt}

Efter OL i Paris i 1924 havde Bukh gjort op med de olympiske leges idé og antydet et andet ideal: »Hele olympiaden virkede overbevisende om, at de moderne olympiader i deres nuværende form snart er færdige. Det hensynsløse begær efter førsterang, der er så alt overvejende på olympiaden nu, ejer ikke livskraft eller værdi, og noget andet og herligt, der er i ungdommens ideal, vil snart kræve plads, også på ungdommens verdensfest, som olympiaderne bør være «. ${ }^{9}$ Siden dette OL havde han arbejdet med planerne om en »olympiade, hvorfra al konkurrence skulle være udelukket«. I sommeren 1929 var planerne færdige til en fest i 1930, som samtidig skulle være en 10-års jubilæumsfest, men planen måtte udsættes, eftersom de nordiske lande ikke kunne deltage, da de hver for sig skulle afholde nationale gymnastikfester. ${ }^{10}$

Igen i 1933 havde Niels Bukh lanceret ideen om en »stor og ideel olympiade eller international gymnastikfest i Ollerup «. Men efter presseblæsten samme år i anledning af hans skamrosning af det nazistiske Tyskland, havde han opgivet at afholde stævnet, fordi: »Landets presse og statssty- 
relsen nærer vel næppe nu den tillid til mig, der er nødvendig for godt samarbejde om en sag som denne $\ll .{ }^{11}$ Dertil kom, at der blev afholdt OL i Berlin i 1936, og at valutaforholdene vanskeliggjorde gymnastikrejser over landegrænserne. ${ }^{12}$

Svendborg Avis kritiserede i 1934 Bukh for at give pressen skylden, i stedet for at erkende at han selv var skyld i miseren. Især faldt det avisen for brystet, at Bukh havde beskyldt pressen for, at den har fyldt ham med løgn om jødespørgsmålet i Tyskland $\ll{ }^{13}$ Ikke desto mindre var Svendborg Avis villig til at se bort fra Niels Bukhs politiske fejltrin, for det var kun »den ene side af sagen. Til den anden side har vi den Niels Bukh, der er en fremragende ungdomsleder, en evnerig idrætspædagog, elsket af sine elever og beundret $i$ alle kredse af vort folk. Den Niels Bukh har altid været omfattet af sympati af hele pressen, og at vi på andre punkter har haft noget udenforstående med ham har ikke gjort noget skår i denne sympati ... Derfor tør vi også forsikre, at havde forstanderen besluttet sig til at afholde olympiaden næste år, ville pressens støtte ikke have manglet $\ll .{ }^{14}$

I stedet for den internationale gymnastikfest lykkedes det Bukh i 1935 at afholde et landsstævne, som i hans vanlige grandiose stil blev lagt an som en »nordisk olympiade «. Den nordiske olympiade var dog fortsat en »forprøve til den ideelle, internationale olympiade«, han stadig havde i tankerne. Bukhs mål var, at den nordiske olympiade skulle være »mere omfattende og indholdsrig end nogen tidligere ungdomsfest i Danmark «. ${ }^{15}$

Gennem inddragelsen af de andre nordiske lande, lykkedes det ham at skabe en profil på stævnet, som langt bedre end det noget landligt klingende »landsstævne « kunne appellere til bybefolkningen. Stæv- net medførte også en udvidelse af landsstævnekonceptet ved, at gymnastikken nu blev forbundet med en lang række andre kulturformer, og at konkurrencesporten var med. Valget af olympiadebegrebet var et udtryk for, at Bukh opfattede sig som en mindst lige så legitim arvtager til de antikke lege som Pierre de Coubertin og hans moderne Olympiske Lege. Paradoksalt nok blev det netop Bukhs politiske samarbejdspartnere de nazistiske sportsledere, som med Berlinlegene i 1936 for alvor befæstede Coubertins olympiske koncept, skønt også de var stærkt kritiske overfor den individualistiske sport, men herigennem så en mulighed for at propagere det tyske folks racemæssige overlegenhed.

Niels Bukh holdt sig under stævnet tilbage med direkte verbal støtte til nazismen, hvilket $i$ en del af især den radikale landbopresse blev udlagt som et resultat af, at han »selv har kundgjort «, at han for fremtiden kun vil »tage vare på sin gymnastik. Jeg er ikke politiker, siger han. Og kan han holde sig $\mathrm{i}$ skindet, så godt det samme $\ll{ }^{16}$

På trods af Niels Bukhs eventuelle proklamationer lykkedes det ham, i en lancering af planerne til stævnet i 1935 på en subtil måde, at fremhæve betydningen for den danske selvstændighed af Tysklands velvillige syn på Danmark som en nordisk kultur, samtidig med at han tilsyneladende bakkede op om folkestyreideen. I Skytteog gymnastikforeningernes blad skrev han, at det ikke var nok, at »vore store naboer beundrer kraften og sundheden i vor nordiske kultur. Vi skal selv se den, glæde os over den og samles om den i fornem, national stolthed, thi først da ejer vi den ret og hæver den, som kulturen kun kan hæves af et folk, der lever i frihed og under sundt folkestyre «. ${ }^{17}$ Initiativer som Bukhs »olympiade« skulle derfor ses som en ga- 
rant for, at Tyskland ikke ville føle grund til at true dansk suverænitet.

Olympiaden foregik ikke i et roligt hverdagssamfund, men i en stemning af politisk opbrud, hvor kommunister og nazister var i offensiven, KU havde opnået et kulminationspunkt på 30.000 medlemmer, ${ }^{18}$ og den med nazismen flirtende Landbrugernes Sammenslutning (LS) oplevede sin glansperiode og formåede på baggrund af et kriseramt landbosamfund at samle 40.000 aktivister $\mathrm{i} »$ Bondetoget « til Kongen. I avisreportagerne gik beskrivelsen af olympiaden nærmest direkte over i beretningerne om Bondetoget, som foregik umiddelbart i forlængelse heraf. I landbokulturen må Bukhs gymnastik have fået en ekstra stærk symbolværdi gennem dens demonstration af, at der også fandtes offensive og skabende aspekter på landet og ikke kun LS's desperate og ydmygende petitioner om hjælp.

\section{Stoevnets ceremoniel}

»Den nordiske olympiade « blev afholdt på Ollerup Gymnastikhøjskole den 25. til den 28. juli 1935. Olympiaden var det første landsstævne efter Dybbølstævnet i 1928. Ved stævnet dyrkedes de konservative idealer om »Gud, konge og fædreland «, og hverken prædiken, kongebes $\emptyset \mathrm{g}$ eller militærets $\varnothing$ verstbefalende savnedes i de dage. Olympiaden blev et nationalt og nordisk overflødighedshorn med opera, orkestermusik, ballet, dans (herunder folkedans), optog, sang, recitation af store scenekunstnere, flyopvisninger, kongebes $\varnothing \mathrm{g}$, friluftsprædikener, massekoreografier, sport og gymnastikopvisninger af nordiske »landshold « og danske amtshold på op mod 1000 deltagere. Der blev også komponeret en særlig »landsstævnemarch«.

Stævnets officielle arrangør var DDSG
\& I, mens Niels Bukh under hele arrangementet var »Overbestyrelsens rådgiver $\ll .{ }^{19}$ Stævnets protektor var Kongen, og i præsidiet sad statsminister Stauning, den radikale indenrigsminister Dahlgaard og hærchefen general With. ${ }^{20}$ Undervisningsminister Borgbjerg og teaterchef Andreas Møller ved det Kongelige Teater var indgået i et samarbejde om at skaffe kunstnere fra det kongelige Teater, og gennem Undervisningsministeriet var der sket henvendelse til de $\emptyset$ vrige nordiske hovedstæders nationalscener. ${ }^{21}$ Stævnet havde et stærkt militært islæt. Der var reveille hver morgen kl. 6:30, flaghejsning kl. 9, militær kunstflyvning og organisering af deltagernes store teltlejre med »generalkommandoens lejrinspektør« som leder. General With med stab overværede olympiaden.

Stævnet havde i udpræget grad pressens positive bevågenhed, ${ }^{22}$ og fik på grund af vejret et dramatisk forløb fra besvimelser på grund af varme, til en vindstyrke der skubbede gymnaster ned fra bommene og jagede publikum bort. Stævnet blev på sit højeste besøgt af omkring 50.000 tilskuere, og var med sine 14.000 udøvere angiveligt »det største nordiske idrætsstævne, der... nogensinde havde været afholdt $\ll{ }^{23}$ I alt gav 78 regionale hold opvisning.

I pressen hyldedes stævnet som en mulighed for en stærkere enhedsfølelse blandt de nordiske folk og for dets enorme dimensioner. BT skrev, at »Det er noget hidtil aldrig set i Danmark, et skuespil, hvis karakter og dimensioner man ikke umiddelbart har kunnet forestille sig... 14.000 unge mennesker, koncentreret på ét sted, fylder så stærkt op, at både de selv og vi andre, der til en vis grad er udenfor det hele, næsten taber vejret, når vi ser dem $\ll .{ }^{24}$

Stævnet markerede, at Niels Bukh for alvor havde fået marginaliseret skytterne og med dem hele gymnastik- og skyttebe- 


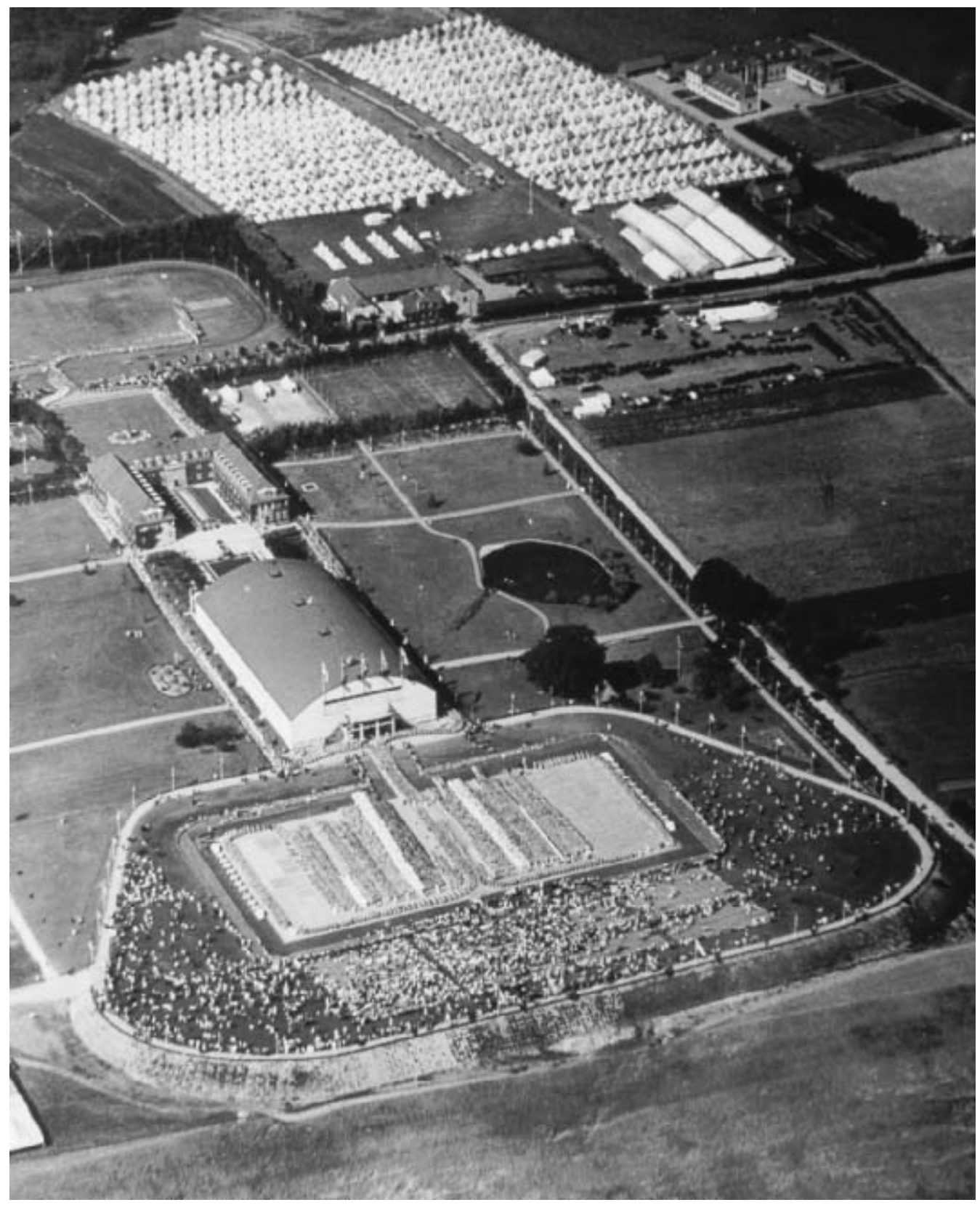

Åbningshøjtideligheden ved Den nordiske olympiade i 1935 med teltlejr for hhv. mand og kvinder $\phi v e r s t$ th. og Bukhs stadion fra 1923 i $\phi$ verste venstre hjørne. Nederst ses den nybyggede stcevneplads »Volden « med de opmarcherede hold omkranset af tilskuere. Kilde: Pressefoto fra arkivet på Gymnastikhøjskolen i Ollerup (OA). 
vægelsens begrundelse i arven efter 1864 og forsvaret mod tysk imperialisme. Skydningen var kraftigt nedtonet, idet $\varnothing$ velserne foregik udenfor det egentlige stævneområde, og - hvilket for Niels Bukh personligt var »en stor tilfredsstillelse « - skytterne var "gået med til at deltage uden at der bliver udsat præmier af nogen art «. ${ }^{25}$ Skytterne var kun repræsenteret med 500 mand, og der lød protester mod »Niels Bukhs diktatur «, som hævdedes at have resulteret i, at skydningen var »meget dårligt tilrettelagt«. Det kunne ikke ventes, at skytterne ville rejse langvejs fra til »en afkrog af landet, der havde den dårligste jernbaneforbindelse i Danmark«. Blandt skytter lød der forudsigelser om, at stævnet kunne medføre, at der skete en adskillelse af skytter og gymnaster i DDSG\&I. ${ }^{26}$

Stævnet sparede ikke på brugen af moderne teknik i form af projektørbelysning, styrtebadsanlæg, midlertidig togstation og postkontor, filmoptagelser og et stort højttaleranlæg. Over den monumentale idrætshal vajede Nordens fem flag (inkl. det islandske), og hundredvis af nordiske flag prydede stævneområdet. Det eneste ikkenordiske kulturelement var tysk, idet nogle af Wagners operaarier fra Gralsfortællingen blev sunget med pianoakkompagnement. ${ }^{27}$

Den store kunstudstilling i Idrætshallen og skulpturer ude på anlægget var arrangeret af »de fire statsanerkendte udstillinger $\ll,{ }^{28}$ og blev meget positivt anmeldt af aviserne, dog tilsyneladende mere i storbyend i landbopressen. ${ }^{29}$ Udstillingens kerne var, både hvad angår de 300 malerier og skulpturerne, værker af afdøde og nulevende fynske kunstnere. Blandt malerne var Willumsen og blandt billedhuggerne Kai Nielsen stærkest repræsenteret. Især gjorde Kai Nielsen indtryk gennem sin »mægtige bronzefigur: Leda uden svane«, der var an- bragt »mellem hovedbygningen og svømmebassinet lige over det rislende vandfald «. Også de unge surrealister var repræsenteret, hvilket tyder på, at den meget traditionalistiske Bukh havde givet udstillingskomiteen frie hænder. ${ }^{30}$

Om dagen var der sportskonkurrencer på skolens stadion, mens gymnastikopvisningerne foregik på »Volden«; en nykonstrueret permanent stor opvisningsplads med udendørs trægulv i stævnets egentlige centrum. Hver af de tre første aftener var der kulturelle arrangementer med et eller flere af de nordiske lande som tema. Alle aftnerne indledtes med stævneorkestrets »samlingsmusik « med landenes »nationalkomponister « som Carl Nielsen, Edward Grieg og E. van Eysden. Senere spilledes nationalmelodien, og der var opvisning ved de nationale »landshold « i gymnastik. Undervejs fremvistes Olympiadens største nyskabelse balletmester Svend Aage Larsens tableau over den eller de af nationernes flag, som udgjorde aftenens tema. Det fremgår ikke af kildematerialet, hvem der fik ideen til det levende dannebrog, men et kvalificeret gæt er, at det var Bukh, da det bærer præg af hans svulstige symbolsprog. Niels Bukhs kvindelige gymnaster, som bar kjoler i de nationale flags farver, lagde sig på knæ og bøjede sig frem, så deres rygge dannede flaget. Aftnerne afsluttedes med fakkeltog, festfyrværkeri og fælles aftensang.

Stævnet startede om eftermiddagen med indmarch af samtlige udøvere under ledelse af Niels Bukh. Ceremonien blev transmitteret af Statsradiofonien. Der blev holdt andagt ved sognepræsten i Ollerup, Viggo Clausen, der i sin korte prædiken fremhævede et nordisk kristent fællesskab, symboliseret i korset i de nordiske landes flag. ${ }^{31}$ Den officielle åbning af stævnet blev foretaget af formanden for DDSG\&I, 


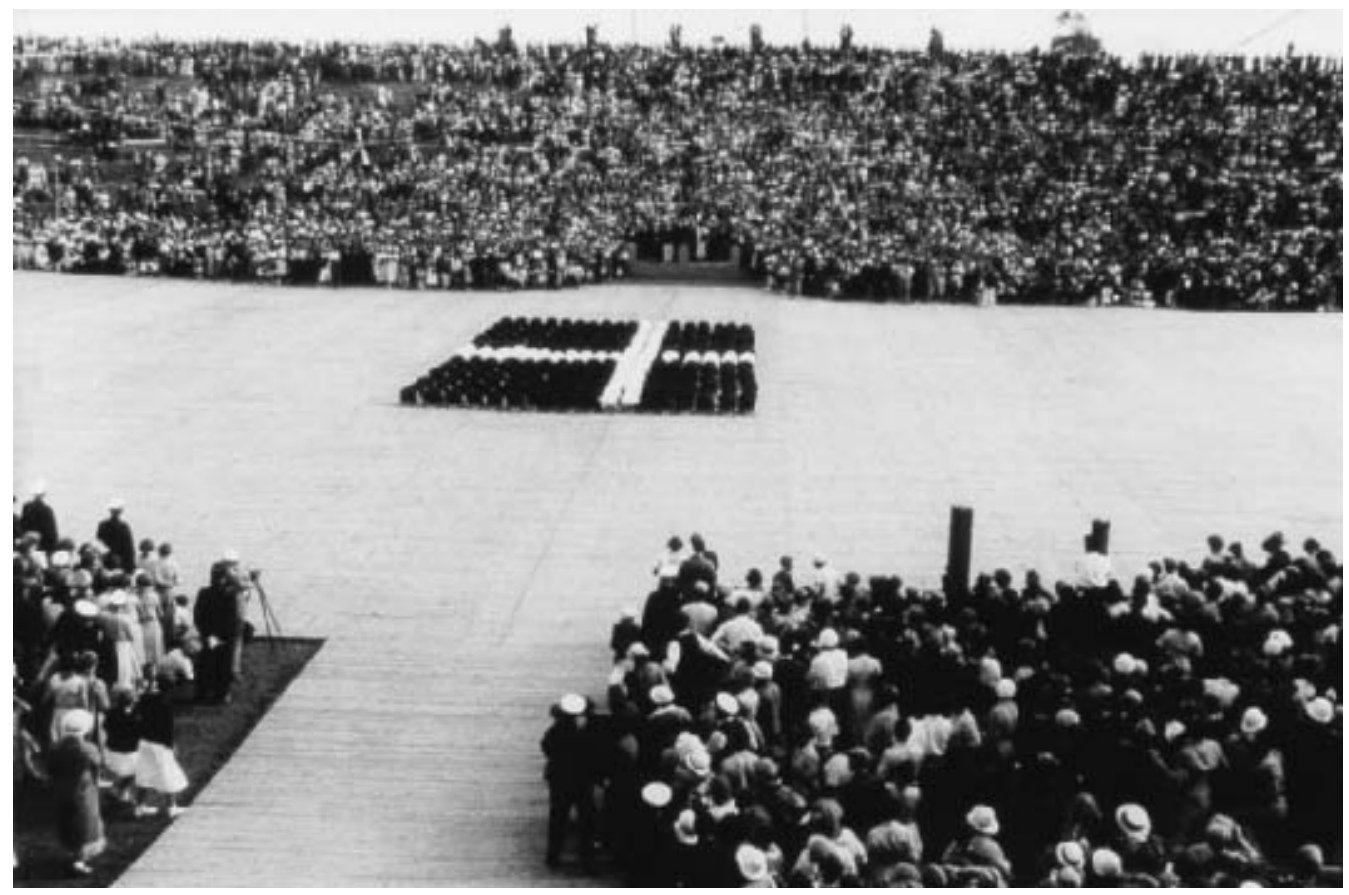

»Det levende dannebrog « foran kongelogen $(O A)$.

folketingsmedlem Arnth-Jensen, som i skyttebevægelsens ånd henviste til 85-årsdagen for $»$ Istedslaget «, hvor det var »Nordens ungdom«, »som på valpladsen stred for Danmarks sag«, idet han henviste til den »skare af Nordens ungdom «, »som nu står opmarcheret «. ${ }^{32}$ Derpå fulgte en prolog af den højreradikale digter Valdemar Rørdam. ${ }^{33}$ Åbningen afsluttedes med en opvisning ved Niels Bukhs store kvindehold, der indviede den til lejligheden oprettede festplads.

Efter 4 gymnastikopvisninger med fynske hold indledtes den »danske aften « med orkesteropførelse af »Danske toner« og Kuhlaus ouverture til det traditionalistiske nationaldrama »Elverhøj«. Dernæst kom den kongelige skuespiller Poul Reumert frem på gymnastikhallens balkon og fremsagde »Der er et yndigt land «, hvilket gav stærkt genlyd i pressen. Politiken skrev:
»Han sagde 'DER ER ET YNDIGT LAND', og alle lyde forstummede. Han sagde hele digtet, ord for ord, linje for linje, og det var som om det hørtes for første gang, som om det blev til i det øjeblik... Han brugte ikke højtaleren, hans stemme klang langt ud over egnen. Tonen i denne røst lod sig ikke standse«. Herefter dannede sommerpigerne et dannebrog med deres rygge. Først marcherede en gruppe ind på opvisningspladsen klædt i røde chiton dragter. De dannede så i fire store grupper, flagets røde felter. Derefter fulgte piger iklædt hvid silke, som krydsede et kors mellem felterne.

I pressen var der en stærk fascination af gymnasternes koreografi. Det journalisterne især henviste til var, at pigerne levendegjorde danskheden. Det var et symbol på Dannebrog, som »levede « og »åndede«, »en levende korsdug «. Selv den radikalt 
farvede Politiken overgav sig helt: »Der stod flaget lidt usikkert i linjerne. Men pigerne rykkede tættere sammen. De lagde sig på knæ, de lagde sig helt med panden mod gulvet, og der lå endelig det færdige dannebrog skabt af unge kvinder, hvis spændte rygge levede yndefuldt $i$ aftenskumringen. Mange har brugt og mange har misbrugt flaget, men denne fane, som åndende lå udbredt midt i en fynsk mark, vakte ærefrygt. Uvilkårligt, uden tøven rejste alle sig og blev stående tavse, mens pigerne stod op fra gulvet, og marcherede ud «. ${ }^{34}$ Især vakte det begejstring, at det var kvinder som legemliggjorde det danske flag. Under overskriften »Det smukkeste dannebrog « skrev den konservative Århus Stiftstidende: »Vi så nu det smukkeste dannebrogsflag, som nogensinde er oprullet. Dette aldeles tydelige danske flag, og dog bevidstheden om det kvindelige hjertebankende element, det var dannet af, inderliggjorde flagets symbolik. ${ }^{35}$

En sådan følelsesfuldhed blev ikke tillagt mændene, som eftersom de i retstilling fremviste en pansret og stærk, kollektiv positur, og da det i reglen var én af mændene, som bar fanen, utvivlsomt snarere gav tilskuerne associationer til et forsvarsværn for »Fædrelandet «, der som en levende mur markerede en stærk nation med faste grænser. $^{36}$

$\mathrm{Nu}$ trådte den store forkæmper for den sønderjyske sag H.P. Hanssen frem i projektørlyset. Ligesom Arnth-Jensen fors $\varnothing g-$ te han at dreje stævnet $\mathrm{i}$ retning af den traditionelle front mod tysk imperialisme. Også han tog udgangspunkt i den danske sejr i 1850: »Og så har vi vort dejlige Dannebrog under hvis rød-hvide kors vi netop i dag for 85 år siden vandt en sejr ... Det vajede dengang over vor kæmpende hær ...« H.P. Hanssen fortsatte med en slet skjult henvisning til Tyskland: »Godt nok er vi et lille land, men dansk ingeniørkunst og dansk landbrug er kendt verden over ... Vel er der mørke skyer i horisonten ... men lad os råbe et trefoldigt hurra for vort fædreland «, derefter sang man H.C. Andersens »I Danmark er jeg født «. Resten af aftenen var der opvisninger af Niels Bukhs mandlige »landshold « og det kvindelige »landshold« ledet af Snoghøjs Jørgine Abildgaard samt flere recitationer, fremførelser af korværk og et balletarrangement.

Den anden dag ankom den danske kongefamilie med Christian den tiende i spidsen til stævnet. Den royale tilstedeværelse virkede som en tilskuermagnet, og 50.000 var mødt op. Pressen berettede om Bukhs grove taktløshed, da han prustende havde banet sig vej gennem menneskehavet for at modtage kongen og denne noterede sig, at Bukh kom for sent, hvortil Bukh svarede, at det var majestæten, der kom for tidligt.

Den danske flagkoreografi vistes igen, denne gang lige ud for »kongelogen «. Efter en tale af Arnth-Jensen, holdt de nordiske »landshold « opvisning for kongen. Senere var der »svensk aften« utvivlsomt som en fejring af prinsesse Ingrids tilstedeværelse. Én af Sveriges mest anerkendte teaterskuespillere Anders de Wahl fra det svenske Kongelige Dramatiske Teater fremsagde en prolog. Sveriges gymnastikdirektør Axel Berg von Linde holdt en tale, hvori han for det første gav udtryk for at ville lære af Danmark, hvordan man gør gymnastikken til hjertesag. Hermed tænkte han på den særlige danske tradition for frivillig, folkelig gymnastik. For det andet hyldede han grundlæggeren af den lingske gymnastik P. H. Ling og for det tredje Niels Bukh: »Ingen nulevende mand har gjort så meget for legemskulturens udvikling i Norden som Niels Bukh «. ${ }^{37}$ Gennem denne subtilitet fik gymnastikdirektøren 
på én gang udtrykt hyldest til Bukh, men samtidig markeret, at Ling var af større format. Gymnastikdirektøren mente, at stævnet var »det største, som har været afholdt i Norden «. Han kritiserede dog i Svendborg Avis Bukhs mandsgymnastik for en overdreven dyrkelse af styrke og smidighed, der kunne give slappe led og fandt den totalt uegnet som børnegymnastik. To vers fra den svenske nationalmelodi »Du gamla du fria blev sunget som fællessang. Resten af aftenens program bestod af svenske sange, viser, recitation og danse.

Om lørdagen var der opvisning af »Sjællandske Flyverafdeling «. Egentlig skulle 27 maskiner være lettet, men på grund af voldsom blæst nåede kun de 18 frem, og de måtte opgive deres kunstflyvning og fløj blot formationsflyvning hen over stævnepladsen. ${ }^{38}$ Ellers rummede lørdagen den finsk-norske aften. Efter $\gg$ samlingsmusikken « spilledes Jean Sibelius' Finlandia med kapelmesteren fra den danske radiofoni Emil Reesen som dirigent, hvorefter forhenværende udenrigsminister Dr. Moltesen holdt tale for Finland. Som led i aftenens recitationer stod Eyvind JohanSvendsen fra det danske Kongelige Teater for oplæsning af Henrik Ibsens »Terje Vigen «, der som en »symfonisk digtning « med orkestermusik blev uropført ved landsstævnet.

Den sidste dag var der igen opvisning ved de nordiske »landshold « efterfulgt af en fælles indmarch af alle deltagerne. På afslutningsaftenen var alle sejl sat til i form af viser, musik, recitationer, ballet og klassisk sang. General With holdt en hyldesttale til Niels Bukh og den nordiske ungdom. Stævnet afsluttedes med en epilog af Valdemar Rørdam reciteret af Jens ArnthJensen. Bukh kan meget vel have haft en finger med i udvælgelsen af den ultranatio- nalistiske, senere nazist, Valdemar Rørdam, hvis vision var, at folket skulle renses for alt det truende urene:

»Alle som ét legeme, renset - muskel, marv og lymfekar, renset hjerne, ja og hjerte - for hvad dorsk og giftigt var; som et sådant legeme rede til i livets kamp og spil snart at bøje sig og bære, snart at gribe og slå til «. ${ }^{39}$

Epilogen rummede et hyldestdigt til hver af de fire store nordiske lande og kulminerede i en hyldest til »det enige, det samlede og frie Norden«. Der blev markeret en klar afstandtagen til kommunismen og Sovjetunionen ved, at Finland blev karakteriseret ved problemerne med naboskabet til den store nabo mod øst: »På samlet vagt for land og lov mod fremmed tyranni $\ll^{40}$ Hvert af de fire nationale digte efterfulgtes af de forskellige landes nationalsange, og derefter sang forsamlingen $» H \varnothing j e$ Nord, Friheds Hjem«. Til sidst samledes en del af gymnasterne omkring Niels Bukh og bar ham i guldstol ind i Idrætshallen. ${ }^{41}$

\section{Den starke mand}

Det var sandsynligvis Bukhs egne gymnaster, der bar ham i guldstol, men personkulten omkring Niels Bukh havde et langt bredere gennemslag. I pressen var det en udbredt opfattelse, at Niels Bukh havde en særlig magt over sine gymnaster, og på trods af at han umiddelbart lignede en firskåren, lidt korpulent gennemsnitsdansker på 55 år, kunne han selv i store hyldestartikler af Anker Kirkeby i Politiken karakteriseres som et karismatisk »geni«, der »ejer den fødte førers magnetiske udstråling «. Under hans »hænder ranker de unge sig, rejser husene sig, grønnes kløvermarken «. Han var »sprængladet med energi, vitalite- 


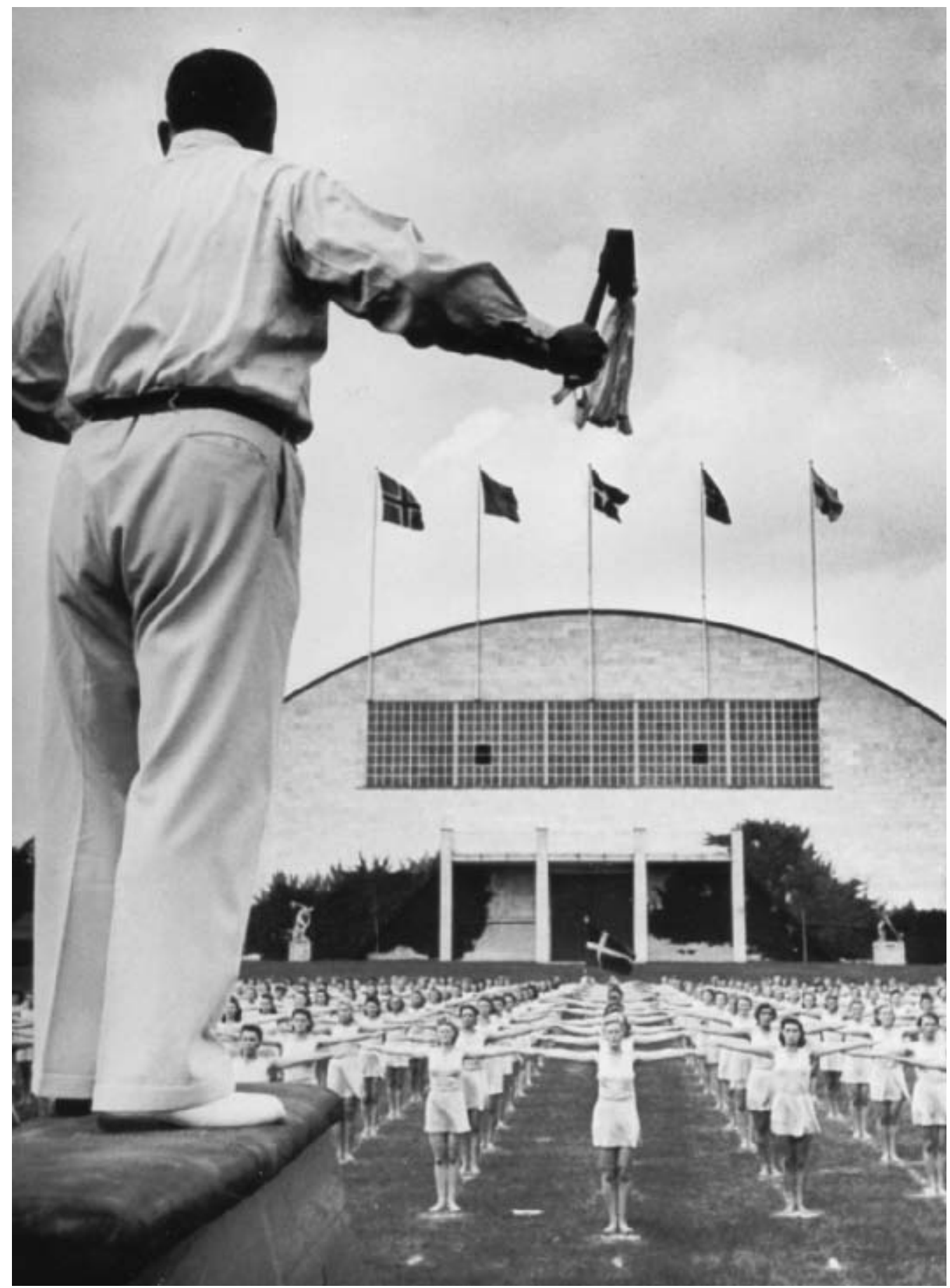

Også visuelt fremstilledes Bukh som en forerfigur. Her er perspektivet oppfra ham og ned mod de mange gymnaster, som lyder hans mindste vink. Pressefoto, OA. 
ten står ud af ham, som elektriciteten af en Leydnerflaske «. Bukh og hans gymnaster kunne legemliggøre Valdemar Rørdams digt om den sammensmeltede folkekrop. I en optaktsartikel til stævnet hed det i Politiken om Niels Bukhs kommando, at: »I samme sekund forplanter suset sig til salen... skaren rammes af elektrisk stød... det er ikke to hundrede pigebørn, det er ét væsen, der nu samtidig løfter sine hundrede arme mod loftet... Hans ydre virkemidler er næsten umærkelige, en svag bøjning af den ene hånd, kommandoerne knap hørlige, de virker som rent sjælelige eksplosioner «. Niels Bukh står »selv urokkelig som en statue. Her er han på sin højde, hans førerevne gnistrer som en aura om ham, den massive skikkelse formelig sender stråler af kraft og vitalitet ned gennem alle de to hundrede $\ll^{42}$ Om hans marcherende karle og piger skrev BT, at de var »i dette øjeblik behersket af den stemning, som manden Niels Bukh på næsten mystisk vis formår at meddele til dem, der er under hans kommando $\ll{ }^{43}$

Den konservative Jydske Tidende skrev, at Niels Bukh skiftevis »tryglede og besværgede, truede og talte som kammerat til kammerat. Det var, som der udgik hypnotiske udstrålinger fra ham, og de 200 unge piger fulgte ham lydigt og villigt. Det man her så var en skønhedsåbenbaring af den anden verden... I et sådant $\varnothing j$ jeblik er Niels Bukh et geni, i de omgivelser skal man se ham, og i den gerning skal han anskues: Som kaptajnen på kommandobroen, som den ene rådende vilje for en fallanks af ungdom. Han er da en hypnotisør og en magiker $\ll{ }^{44}$

Enkelte udtrykte dog betænkelighed ved den stærke dyrkelse af Niels Bukh som et gymnastikpædagogisk geni. Hans hovedrival på kvindegymnastikkens område Jørgine Abildgaard fra Snoghøj advarede mod en »maskinel præcisionsgymnastik, som gjorde gymnasterne til marionetter i lederens hånd og derved udslettede deres personlighed «. Hun fordrede i kvindegymnastikken den »levende kraft« og ikke den »mekaniske kraft, det moderne menneske tilbeder $\ll .{ }^{45}$ Efter stævnet kritiserede Abildgaard skarpt »det mandsprægede forbillede« i Niels Bukhs kvindegymnastik. ${ }^{46}$ Det skal her erindres, at det på kvindegymnastikkens område nærmest lykkedes for Niels Bukh at stjæle billedet fra Jørgine Abildgaards landshold gennem $»$ det levende dannebrog « fremført for kongen.

Dyrkelsen af Niels Bukhs karisma kunne forbindes med 1930'rnes råb efter »den stærke mand «. Der var ikke kun tale om Konservativ Ungdoms flirt med ideer om autoritære ledelsesformer, heller ikke alene de relativt få kommunisters og nazisters tilbedelse af Lenin/Stalin og Hitler, men også en bredere dyrkelse af »landsfaderen « statsminister Thorvald Stauning indenfor demokratiets rammer, jvf. Socialdemokratiets slogan ved valget i 1935: »Stauning eller kaos«. Behovet for at dyrke sådanne samlingsfigurer må have været ret stort, siden selv den del af pressen, der var kritisk overfor Bukhs politisering, så kort tid efter Bukhs opslutning bag det tyske førerprincip, kunne bruge ham som symbol på den stærke leder.

Jordomrejsen i 1931 havde ikke medført den grad af persondyrkelse, som nu skulle blive Niels Bukh til del. På trods af, at store dele af stævnet var arrangeret af DDSG\&I, blev arrangementet som sådant nærmest alene tillagt Bukh. Dyrkelsen af Niels Bukh som »stærk mand « foregik i reglen ikke i den direkte politiske betydning af ordet, men derimod i bredere forstand som en karismatisk leder- og entreprenørtype. Den nordiske olympiade blev af og til benævnt »Bukhstævnet«, og han 
blev omtalt som en »stærk mand«, »hærfører«, »Napoleon« og »feltmarskal«, og endnu hyppigere som »troldmand « og »høvding«. Også i avisernes billedsektioner var han fremtrædende, ikke mindst på fotos hvor han optrådte i en »kinky« fremtoning med tropehat og hvidt tropetøj gestikulerende med sin »dirigentstok«, der havde et hvidt lommetørklæde bundet for enden. Fotos af Niels Bukhs møde med kongen blev også hyppigt vist. Et yndet motiv var, da kongen præsenterede Bukh for kronprins Frederik og kronprinsessen. ${ }^{47}$

Pressens dyrkelse af Niels Bukh spillede på den aktuelle historie om, at han på ganske kort tid fik planlagt, udgravet og omplantet et stadion med tilskuerpladser til Den Nordiske Olympiade. Dertil kom historien om hans vej fra fattigdom til succes, idet han for 20 år siden havde stået uden den store kapital på en stump sydfynsk jord, men nu havde nået verdensberømmelsen og fået opført et idrætskompleks med Nordeuropas angiveligt største idrætshal og Danmarks første indendørs svømmehal.

Den konservative Randers Amtsavis udkom med overskriften »De 14.000 gymnaster under én mands kommando « og fokuserede på Niels Bukhs selvfremføring og mission: »Han er i hvid tropedragt og har den elfenbensknappede ibenholtstok $\mathrm{i}$ hånden som en marskalstav - Noget $\mathrm{i}$ den retning har han også lov til at føle sig «. Synet satte tanker i gang hos journalisten, som så frem til »den dag, da mange, mange flere end disse 14.000 af Danmarks unge får så ranke rygge, så stærke arme og ben, så vældige muskler $\ll$. ${ }^{48}$

Dagens Nyheder dyrkede helt uden omsvøb Niels Bukh som stærk mand: »Det er blevet sagt om den danske nation i disse år, at det skortede på enkelte store førerbe- gavelser. Dette skulle bl.a. være forklaringen på, at bevægelser baseret på diktaturets idé aldrig kunne finde sangbund her i landet. Ondskabsfulde tunger har talt om Danmark som middelmådighedernes land og henvist til, at det danske temperament var af en sådan beskaffenhed, at det ikke egnede sig til frembringelsen af høvdingetyper. Hvad da med Niels Bukh? Han står i dag på sit livs højde - sejrrig, stræbende mod nye idealer, kampglad og sikker, en fører af verdensformat indenfor sit område. Journalisten forsikrede, at hvad der var »vigtigst af alt«, Bukh var »så gennemdansk fra yderst til inderst, som nogen kan ønske «.

Journalisten mente, at der burde rejses et monument over Niels Bukh, men ikke endnu, for han står fortsat »udstrålende en vanvittig magt over hele denne sunde, solbrændte ungdom, en gigantisk personifikation af egne ideer. Niels Bukh! Niels Bukh, som de alle sammen er dus med..... Niels Bukh som de alle sammen skælver for... Niels Bukh som de alle sammen elsker og følger... Helten, føreren og kammeraten, dagens mand i Danmark «. Også Niels Bukhs barske pædagogik kunne hyldes efter devisen jo mere brutalitet jo mere hengivenhed. Journalisten havde overværet en natlig prøve på kvindernes gymnastikopvisning, og Niels Bukh sagde til: »Marie, at hvis hun var hans datter, fik hun smæk. Og han spurgte med tordenrøst Inga med det blå bånd, hvorfor i alverden hun gjorde sig umage for, at gøre sig grimmere end hun var i forvejen... Jo mere Niels Bukh ærtede og smertede, jo mere tilbedende så de på ham $\ll^{49}$

I et enkelt tilfælde blev der udtrykt et direkte $\varnothing$ nske om at bruge Niels Bukhs lederevner i den politiske styring af landet. Hofjægermester Sehested, som senere under besættelsen søgte at opnå Bukhs deltagelse i en nazistisk regering, havde allere- 
de under Olympiaden et godt blik for Niels Bukhs førerevner. Efter én af Bukhs opvisninger udtalte han: »Tænk om vi havde sådan en mand til at lede landet! «. Umiddelbart efter tog Sehested med Bondetoget til København, hvor han, som journalisten noterede sig, var én af hovedtalerne. ${ }^{50}$

Det var dog ikke alle, der betingelsesløst overgav sig til dyrkelsen af den stærke mand. Århus Stiftstidende spurgte bekymret om Den nordiske olympiade var udtryk for, at det er »idrættens ånd, der har sejret, eller er det en enkelt stærk mand, der viser vej? $\ll{ }^{51}$ I en artikel, der blev trykt i både radikale aviser og i venstrepressen, advaredes der mod personkulten omkring Niels Bukh og mod at overføre idrætspædagogiske principper på politiske forhold: Først krediteredes Niels Bukh for at gøre de stive, slidte, uharmoniske bønderkarle til »antikke statuer i kød og blod «: »Dette er Niels Bukhs indsats, for den bøjer man sig. Og når det er sket, undser man sig slet ikke ved at gå i rette med de geschæftige folk, der i denne tid har så bandsat travlt med at lobhudle deres helt, at man nærmest får indtrykket af, at den mand, der råder på Ollerup er noget nær Vorherre selv«. Artiklen vendte sig mod omtalen af Bukh, »som en ny slags Grundtvig «, for: »Når alt kommer til alt er kroppen, der er Bukhs domæne, dog kun det mindre væsentlige. Det afgørende er den ånd, der huses i den, og med den side af tilværelsen befatter Bukh sig kun lidt eller slet ikke - og endda kan man trygt tilføje: I de tilfælde, hvor han gør det, synes man, at han hellere skulle have ladet være. Som politisk retningslinje er begreberne kæft, trit og retning en pestilens. I gymnastiksalen derimod er det noget andet, deraf Bukhs misforståede begejstring for Det tredje Rige «. ${ }^{52}$

En radikal avis citerede en ung gymnast for følgende indirekte kritik af dyrkelsen af
Niels Bukh: »Selvfølgelig er der nok mange af de unge, der møder her, som vil blive skuffede. De tænker sig nemlig en storstilet opvisning, hvor enhver gymnast eller sportsmand vil komme til at brillere og blive set, og så er sandheden jo den, at vi allesammen bliver til nittere, der skal være med til at danne den store ener. Men det har vi ikke tænkt på før «. ${ }^{33}$

\section{Den tyske forbindelse}

I pressen blev det meddelt, at den tyske Reichsportführer Hans von Tschammer und Osten ville komme med fly fra Berlin på stævnets sidste dag. Allerede ved et m $\varnothing-$ de på Gymnastikhøjskolen mellem ham og Niels Bukh i marts 1935 havde Bukh informeret von Tschammer om Den Nordiske Olympiade, og rigssportsføreren udtalte til den danske presse, at han ville komme »flyvende til Niels Bukhs store internationale stævne «. ${ }^{54}$ Von Tschammer var uden tvivl reelt interesseret i Bukhs »olympiade«. Et nordisk stævne, som byggede på de nordiske »folks « særegne kropskulturer i en atmosfære af venskabelighed overfor det nazistiske Tyskland var »gefundenes Fressen «.

Med Stauning som medlem af stævnets præsidium er det dog lige så givet, at især socialdemokraterne måtte træde kraftigt på bremsen over for en sådan platform for nazistisk propaganda. Én ting var det uacceptable i tilstedeværelsen af en højt placeret nazistisk politiker ved stævnet, noget andet var den teatralske iscenesættelse med nedstigning fra himlen $i$ et modernitetens symbol; flyvemaskinen, som i miniformat bringer mindelser om Leni Riefenstahls film Viljens Triumf om Nürnbergerpartidagen, som foregik et år før Den Nordiske Olympiade, og hvor hele indledningssekvensen var formet som Hit- 


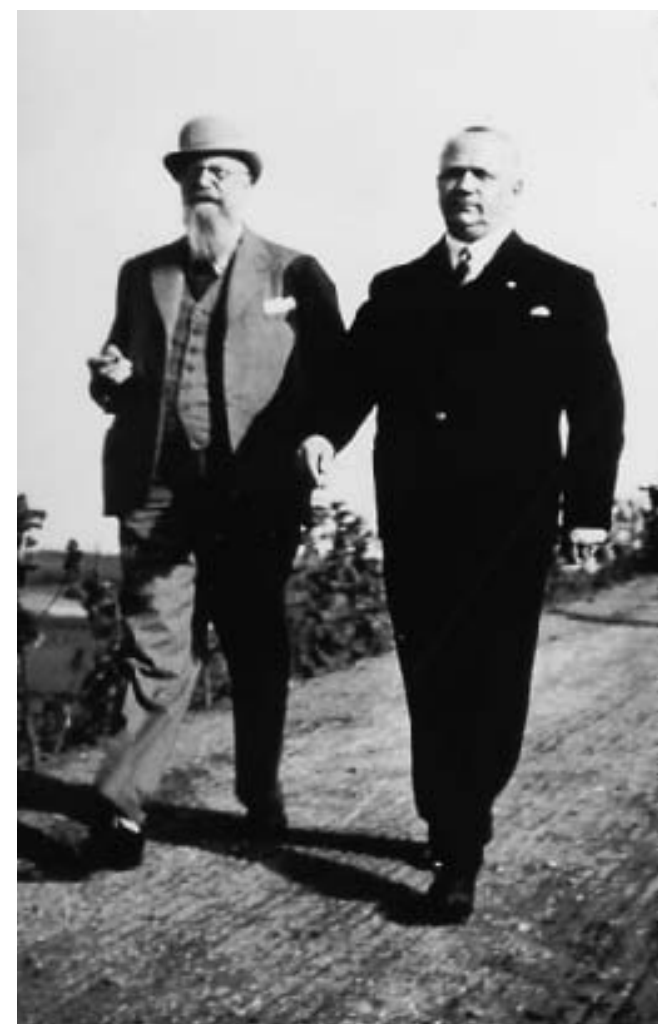

Stauning ved besøg på Gymnastikhøjskolen med udenlandske ministre $i$ midten af 1930'rne. De to går ved siden af hinanden, uden at der spores nogen sarlig kontakt. Bukh bragte først fotografiet $i$ årsskriftet for 1950 .

lers indflyvning til Nürnbergerpartidagene, som »Guden, der stiger ned fra himlen $\ll .55$

Von Tschammer kom da i sidste ende heller ikke til stævnet, hvilket dog ikke nødvendigvis behøver at bero på socialdemokraternes modvilje, men også kan have været påvirket af det kraftige regn- og blæsevejr på olympiadens sidste dag. Heller ikke Stauning benyttede denne oplagte mulighed til at få den brede landbobefolkning i tale, hvilket meget vel kan skyldes en protest mod invitationen af von
Tschammer. Stauning havde dog utvivlsomt også travlt med forberedelsen til en ekstraordinær rigsdag vedrørende landbrugets problemer. ${ }^{56}$ Også undervisningsminister Borgbjerg holdt sig væk, på trods af hans indledende store støtte til stævnets nordiske profil på det kunstneriske område. Den radikale indenrigsminister Bertel Dahlgaard var til stede og medlem af stævnets præsidium, men undlod at holde tale. Den radikale højskoleforstander Bukhs svoger Lars Bækhøj fandt, at stævnet virkede »tomt, pralende og udvendigt«, uden at det »for så vidt fornuftige indhold « for alvor kom til udtryk. ${ }^{57}$

Ud over afblæsningen af von Tschammers besøg blev en anden mulig sammenknytning mellem nazisme og landsstævne heller ikke realiseret. Bukh måtte på grund af deltagelse på danmarksdagen ved Verdensudstillingen i Bruxelles den 15. juni, og 14 dage senere ved Verdensudstillingens internationale gymnastikdag, ${ }^{58}$ afslå

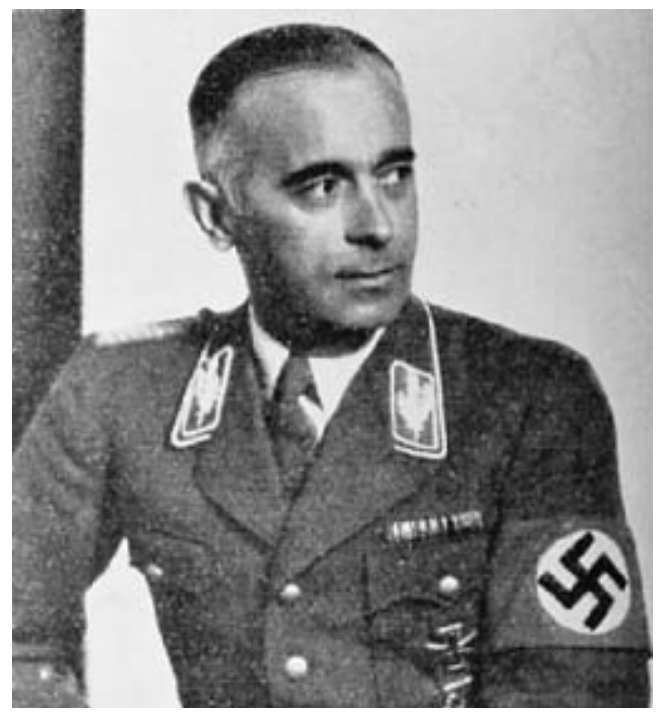

Rigssportsfører von Tschammer und Osten. Kilde: Arsskrift for Gymnastikhøjskolen, 1936. 
at give opvisning ved Nordische Gesellschafts anden »Reichstagung « $\mathrm{i}$ måneden op til Den nordiske olympiade. ${ }^{59}$

Socialdemokraten kritiserede Niels Bukh under overskriften $»$ Niels Bukhs diktatorlyster «: »Der har været megen skønhed i disse dage, men programmet har også budt på en god portion nationalisme, grundtvigianisme, patriotisme og flere andre ismer... der går historier om at stævneledere, arrangører og politi har været nødt til at sætte Niels Bukh stolen for døren for at imødegå de midler, hvormed Niels Bukh har søgt at gennemtrumfe sine planer«. Der var også lystighed over, at »den lille mand « åbenbart ikke fik en så ærefuld fortjenstmedalje af kongen, som det var forudset. ${ }^{60}$

I den danske presse var der bred enighed om, at Den nordiske olympiade markerede skabelsen af en ny form for folkefester, ${ }^{61}$ hvorved der helt sås bort fra, om Niels Bukh brugte sit varme forhold til nazisternes æstetiske iscenesættelse af politisk magt som inspirationskilde. ${ }^{62}$ Gennem sin deltagelse $\mathrm{i} » U d v a l g e t$ for kunstnerisk assistance« og »Festudvalget « havde Bukh stor indflydelse på stævnets ceremoniel. At han kan have hentet kraftig inspiration i Tyskland, og at der i det mindste var et slægtskab i udtryksformer, f.eks. med Nürnbergerpartidagene, ${ }^{63}$ ses af Den Nordiske Olympiades gigantiske præg, opdelingen i 4 temadage og blandingen af modernitet og traditionalisme. ${ }^{64}$ Der kan også anes en inspiration i form af teltlejrene og den militære organisering heraf, ${ }^{65}$ morgenlig flaghejsning og sang samt brugen af militærets flyvemaskiner til opvisning. Også i brugen af natten som kulisse kan der spores et æstetisk slægtskab. Om aftnerne og nætterne spilledes der kraftigt på forholdet mellem lys og mørke i de natlige fakkeltog.
Dog har Bukh i sin masseornamentik utvivlsomt også været inspireret af tidligere landsstævner, de olympiske lege som han havde deltaget i i 1912, 1920 og $1924,{ }^{66}$ samt den stærkt nationalistiske tjekkoslovakiske Sokolbevægelses masseopvisninger.

Den tyske nazistiske interesse for stævnet viste sig klart ved, at Fox-film fra Berlin tonefilmede samtlige de $6 »$ landsholds « opvisning, en oplysning den danske presse ikke gjorde noget væsen ud af. ${ }^{67}$

På trods af Niels Bukhs udtalte beundring for den tyske nazisme i 1933, rygterne om den tyske rigssportsførers besøg og stævnets udtryksform med notoriske ligheder med den nazistiske æstetik, valgte den brede danske presse mere eller mindre bevidst at se Den nordiske olympiade som en særegen dansk/nordisk manifestation uden berøringsflader udadtil. Faktisk blev stævnet $i$ en vis udstrækning profileret som en fremmaning af den historiske kamp for dansk selvstændighed. Om H.P. Hanssens oplæsning af danske digteres værker skrev Politiken, at han: »lagde dem alle som en lænke fra støtten på Vesterbro til støtten på Skamlingsbanken $\ll{ }^{68}$ Gennem at nævne de to mindesmærker fik avisen sammenkædet bondestandens kamp for frigørelse med grænsekampen.

Niels Bukh havde benyttet landsstævnet til at søge udsoning med H.P. Hanssen, som havde taget kraftigt afstand fra ham under hans nazistiske agitation i 1933. I invitationen af H.P. Hanssen skrev Bukh: »Jeg beder nu Dem på Danmarksaftenen den 25. juli holde talen for Danmark. Ingen synes mig bedre skikket til denne opgave end netop De «. ${ }^{69}$ Pressen spillede med på mytologiseringen af det tætte forhold mellem Bukh og H.P. Hanssen. I pressen blev det hævdet, at de var »barndomsvenner«, på trods af at H.P. Hanssen var 18 år ældre. 
I Dagens Nyheder blev Bukh endog kædet sammen med H.P. Hanssens kamp for dansk selvstændighed overfor Tyskland. Om Niels Bukhs ansættelse i 1912 hos H.P. Hanssens bror hed det, at han her mødte en anden dansk »høvdingeskikkelse«, H.P. Hanssen. »Således bøjes to danske skæbner sammen igen«. Om Niels Bukhs »ilddåb « som gymnastiklærer i Sønderjylland hed det: »I al hemmelighed gik han der og holdt gymnastiktimer med den danske ungdom. Man mødtes ofte ved nattetid i en gammel lade nede på marken, og man levede i en stadig angst for, at tyskerne skulle opdage det. Niels Bukh har sagt mig derom: - Dernede fik jeg mine første personlige indtryk af, hvad det er AT VÆRE DANSK. Først når man ikke har sin fulde frihed mere, lærer man at skønne på den! $\ll{ }^{70}$ På trods af sådanne fors $\emptyset \mathrm{g}$ på harmonisering af to politiske modstandere var forholdet mellem Niels Bukh og H.P. Hanssen ret køligt under olympiaden. H.P. Hanssen nævnede ikke Niels Bukh i sin tale, og omvendt udelod Niels Bukh i sin beretning om stævnet i Gymnastikhøjskolens årsskrift helt at omtale H.P. Hanssens tilstedeværelse.

Fremhævelsen af den historiske kamp for et dansk Sønderjylland blev kun i en enkelt avis direkte indfortolket i sønderjydernes aktuelle angst for tysk aggression ved grænsen. Formanden for stævnets gymnastikudvalg gårdejer Johannes Juhl, som også var formand for Sønderjysk Idrætsforening, blev citeret for følgende synspunkt: »Samtidig hærder også tyskernes voksende pågåenhed naturligvis sindene hos vore unge. Der spores nu et kampmod, som vi i hvert fald ikke kendte tidligere «. ${ }^{71}$ Juhl var blevet kendt, da han i 1912 som leder af et sønderjysk hold ved et stævne i Malmø nægtede at gå ind under det tyske flag. ${ }^{72}$

\section{Kommunisternes attentat}

Kommunisterne troede ikke på, at Niels Bukh nu holdt sig fra politik. De havde langt fra glemt hans skarpe kritik af sovjetstyret efter jordomrejsen i 1931 og hans opbakning til Hitlers magtovertagelse. For dem blev stævnet en kærkommen lejlighed til at skubbe en kile ind mellem Niels Bukh og den brede danske befolkning. Om natten klæbede de plakater på træer, telefonpæle og på asfalten. Overskriften var: »Dansk Hitlerstævne i Ollerup«, og »hele den danske presse « kritiseredes for at $» j u b-$ le over « stævnet, som arrangeredes efter »bedste tyske mønster med nationalhymne og feltgudstjeneste under mottoet 'for Gud, Konge og fædreland' tilrettelagt for at opgejle ungdommens nationale følelser«. Bukh var

"gået så vidt, at der er indbudt en række tyske naziførere til stævnet, de der er ansvarlige for myrderierne og fængslingerne i Tyskland, repræsentanter for et system, der ikke kender begrebet frihed, men som har ensrettet de tyske sportsorganisationer, der styres af en nazistisk sportsfører. Det hævdes, at Bukhs stævne er et led i forberedelserne af en krig, som alle ved nærmer sig mere og mere«.

Plakaten udmundede i en opfordring til, at: 'Ingen frisindede mænd deltager i Ollerupstævnet' $\ll .^{73}$ I logisk forlængelse af den brede presses forsøg på at se bort fra stævnets berøringsflader med den tyske nazisme, afvistes kommunisternes fors $\emptyset \mathrm{g}$ på et »attentat mod OL-stemningen« over én kam. $^{74}$

Det kommunistiske »Arbejderbladet« forsøgte at få den fynske befolkning til at lægge afstand til Niels Bukh. Det var »ingen hemmelighed, at der har været 'tysk 
luft' på Ollerup de sidste tre uger. Selv Niels Bukhs nærmeste medarbejdere betænkte sig to gange, før de vovede at henvende sig til 'Hans stormægtighed'... 'Niels Bukh er kommet for højt op' siger fynboerne, 'han bliver for stor på det' ' . Efter at have nævnt flere negative episoder med centrum i Bukhs person, sluttede bladet med følgende salut: »Der er tre store mænd, der i øjeblikket står for fald, og det er Hitler, Knutzen og Niels Bukh«, et håb der mentes at blive delt af de mange »småkårsfolk, der på opfordring fra Niels Bukh har prøvet at tjene penge på indkvartering og handelsfolk, der har stillet stader op $\ll,{ }^{75}$ men som angiveligt næsten intet havde tjent. Det vakte tydeligvis kommunisternes vrede, at Niels Bukh behandlede den stærkt konservative generaldirektør i DSB P. Knutzen som æresgæst, idet »generaldirektøren blev ført til sæde af Niels Bukh. Han fik plads i den samme polstrede armstol, som kongen i går benyttede $\ll .{ }^{76} \mathrm{På}$ Bukhs turné i Norge i august 1935 omdelte kommunister i Oslo de samme løbesedler. ${ }^{77}$

Nogle måneder efter stævnet blev den nationale symbolværdi i Niels Bukhs gymnastik og i Den nordiske olympiade inddraget $\mathrm{i}$ forbindelse med polemikken om Poul Henningsens Danmarksfilm, der var produceret på bestilling af Udenrigsministeriet. Niels Bukh faldt afgjort ikke i de danske kulturradikales smag. Hans gymnastik var for stiv og kantet for jazzelskere og hans politiske meninger for højreekstreme. Dog var der et funktionalistisk præg over Bukhs med hans egne ord »rationelle gymnastik « i dens lineære formsprog og i hans brug af primitiv gymnastik til opvisning (»funktion bestemmer form «).

I den første udgave af filmen var hverken gymnastikken eller olympiaden med, hvilket utvivlsomt hang sammen med, at
PH var både manuskriptforfatter og producer. Ved den danske premiere blev PH og mesterfotografen Poul Eibyes filmisk nyskabende værk især i den borgerlige presse udsat for hård kritik på grund af dens uhøjtidelige fokusering på det arbejdende folks hverdagsliv og den jazzede underlægningsmusik. Filmkomiteen med udenrigsminister P. Munch i spidsen besluttede, at filmen skulle ændres, hvilket hovedsagelig blev i konservativ national retning. I den nye udgave indføjedes sekvenser med den nye Lillebæltsbro, Tivoli og dansk hønseavl. Musikalsk indføjedes $\gg I$ Danmark er jeg født « sunget af børnekoret, og »Vi elsker vort land « sunget af Studentersangerne, og der afsluttedes med »Kong Christian . $^{78}$ Dertil kom en længere sekvens fra Den nordiske olympiade, med billeder af tilskuermasserne og et af de store amtshold, dog uden at hverken Bukhs eller olympiadens navn nævntes. PH fik på underfundig vis lagt afstand til gymnastikken ved helt at udelade speakning i klippet med gymnasternes synkrone holdarbejde, mens det i næste sekvens fra en moderne maskinel produktion hed: »Imens gør maskinerne arbejdet «, ${ }^{79}$ en kulturradikal ironi over den stive »maskinagtige « fællesgymnastik og den overflødige udladning af menneskelig energi, som maskinerne skulle erstatte i den funktionalistiske kultur. Ironisk nok repræsenterede både Bukhs elitehold fra Den nordiske olympiade og PHs film Danmark ved Verdensudstillingen i Bruxelles i 1935.

Konflikten om Danmarksfilmen var dybest set en kamp om definitionen på det nationale. De kulturradikale så gerne de konservatives »Gud Konge og Fædreland « og en ultrahøjreorienteret mand som Bukh hægtet af denne definition, hvilket var uacceptabelt for det borgerlige Danmark. Den nationale symbolværdi i Bukhs arbejde var 
for stærk til at kunne holdes ude fra en Danmarksfilm selv under en socialdemokratisk-radikal regering. Niels Bukh var trods sin højreekstremisme og sin manglende afsværgelse af sin nazistiske vækkelse et uomgængeligt inventar i den officielt sanktionerede danskhed.

\section{Konklusion}

På trods af Niels Bukhs nazistiske offensiv i 1933 lykkedes det ham, uden offentligt at afsværge sine holdninger, mindre end 2 år efter at genvinde sin position som national samlingsfigur, dog uden at socialdemokraterne for slet ikke at tale om kommunisterne deltog i hyldestkoret. At Bukh vitterlig havde kæmpet sig tilbage $\mathrm{i}$ hjertet af dansk nationaldyrkelse viste sig ved, at Poul Henningsen måtte finde sig $\mathrm{i}$, at indslag fra »olympiaden« blev indføjet i hans danmarksfilm. »Olympiaden« markerede, at bondestandens historiske kamp for frihed og demokrati fra neden blev udfordret af strømninger, den havde mere til fælles med borgerskabets prisning af Gud, konge og fædreland. Så længe Bukh blot var kendt som højreradikal med en vis affinitet til nazismen, men uden offentlige besyngelser af racelære og antisemitisme, var han tydeligvis ikke blot accepteret, men hyldet som én af nationens store sønner i brede dele af offentligheden.

Den nordiske olympiade var sandsynligvis det til dato største massearrangement $\mathrm{i}$ landbokulturen og markerede i sammenhæng med det samtidige Bondetog et ryk væk fra folke- over mod massebegrebet, hvor den enkelte deltagers individualitet fortonede sig i dyrkelsen af den store ener. ${ }^{80}$ Der var således under olympiaden helt ud i den radikale presse tendenser til at hylde Niels Bukh som »stærk mand« med en $»$ Kraft durch Freudeagtig « sprogbrug.
Bukhs fortsatte dæmpning af sin offentlige agitation for Det tredje Rige bragte ham langt mere i overensstemmelse med den traditionelle grundtvigianske forstanderrolle, end det havde været tilfældet under hans politiske offensiv i 1933. Ikke desto mindre udviklede Bukh landsstævnet til en form for landbostandens partidag med lån fra nazismens æstetik og militære organisation og med wagnerske operaarier, og stævnet gav uden tvivl de nazistiske idrætsautoriteter endnu et signal om Niels Bukhs potentiale som skaber af et nordiskgermansk formsprog. At dette ikke faldt stærkere i øjnene i Danmark, er et tegn på, hvor ens udtryksformer de völkisch-nazistiske $^{81}$ og de dansk-folkelige ritualer kunne betjene sig af. Og det viser, hvor genial Niels Bukh var til at finde og udvikle netop de punkter, hvor de væsensforskellige ideologier konvergerede.

Olympiaden blev genstand for en mere eller mindre bevidst kamp om stævnets symbolværdi. Dets politiske betydning var ikke givet alene i kraft af dets program, men blev også formet undervejs gennem datidens fortolkninger og »symbolkampe $\ll$. Lovprisningen af det nordiske særpræg var et tveægget sværd. Hvis det nordiske blev forbundet med det ariske ville olympiadens betydning glide over mod det nazistiske, væk fra den dansk/nordiske højskoletradition og folkestyreide. Dyrkelsen af »den stærke mand« ville blive til en egentlig Führerdyrkelse. Opfattelsen af olympiaden var under fare for helt at kæntre, da det blev kendt, at rigssportsfører von Tschammer und Osten efter invitation af Niels Bukh havde planlagt at flyve til Ollerup og lande på en mark nær stævnepladsen, hvilket dog ikke blev realiseret, sandsynligvis fordi Bukh ikke turde udfordre socialdemokraterne ved en så stærk gestus.

Skønt Niels Bukhs olympiade indgik i et 


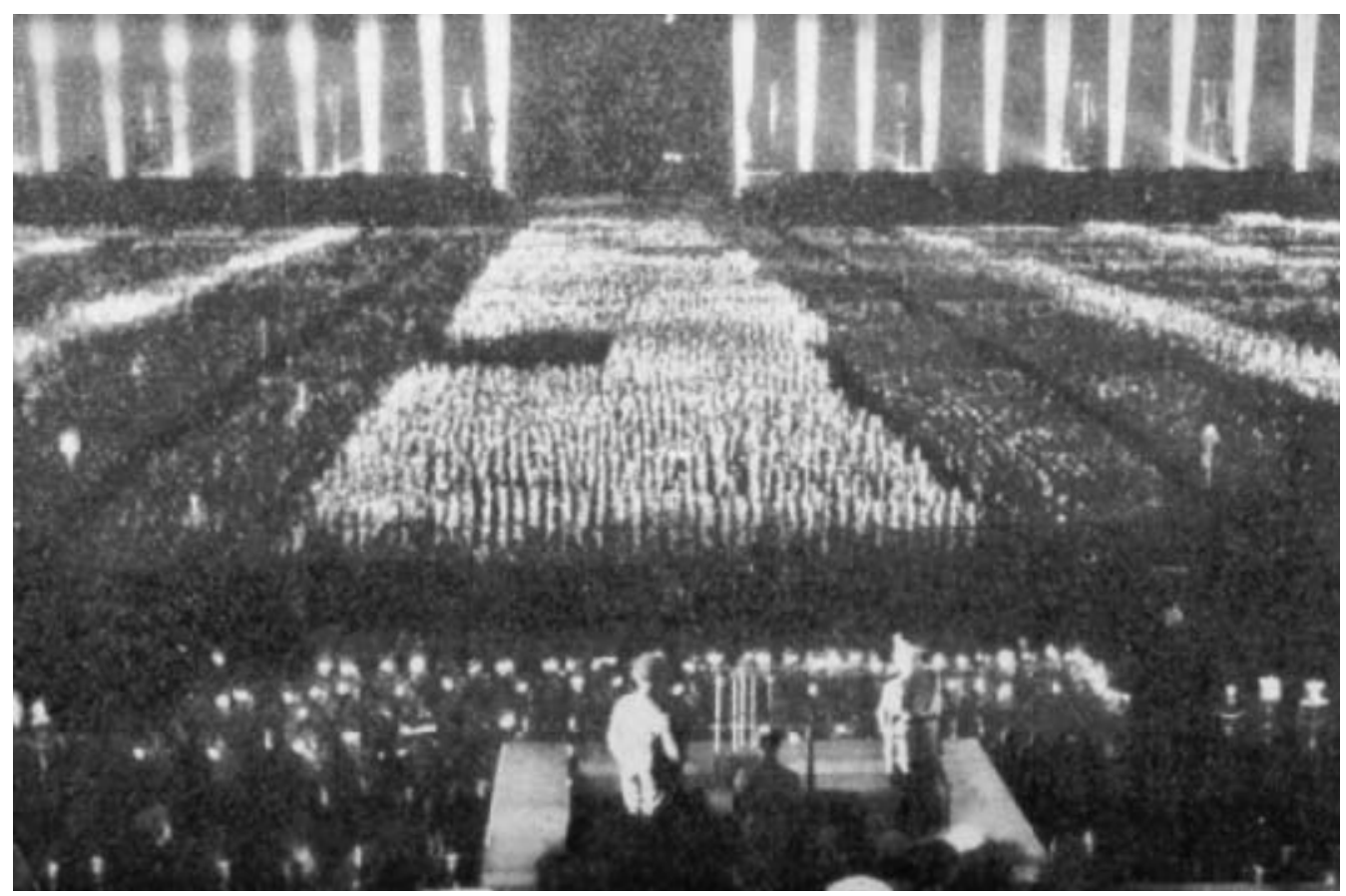

Bukh var så betaget af at overvare lysscenografien ved Nürnbergpartidagene i 1936, at han bragte et foto heraf $i$ sit årsskrift 1936. Ved forstørrelse af fotografiet ses Hitler klart til højre på podiet.

generelt forsøg på at opruste de kulturkonservative værdier og styrke landbokulturen, viste det sig kort tid efter, at de politiske vinde blæste i en anden retning. Med valget i oktober 1935 opnåede Stauning nærmest status som Danmarks »stærke mand «, men på et ubetvivleligt demokratisk grundlag. Med Staunings ophøjelse til landsfader blev rummet for andre stærke mænd kraftigt indsnævret.
Politisk blev Den Nordiske Olympiade et tvetydigt symbol, som dyrkede det nationale, uden i mindste måde at pointere at en god dansker nødvendigvis også var en god demokrat. Bukh stod nu så stærkt nationalt, at han ikke mindst i kraft af sine tyske politiske samarbejdspartneres fortsatte fremgang måtte påregnes at blive mere og mere vanskelig at styre for de demokratiske kræfter i Danmark. 


\section{Noter}

1. 25/7, 1935. Nærværende artikel er i en anden version udgivet på engelsk, jvf. Bonde, 1995.

2. Den lingske gymnastik var en naturvidenskabeligt begrundet sundhedsgymnastik skabt af den svenske digter og gymnastikpædagog Pehr Henrik Ling (1776-1839).

3. Jvf. Jørgensen, 1997, s. 220 og 226f.

4. I Feldbæk 1992, s. 9-336.

5. Jvf. Ehn, 1993, afsnittet »Kropp och känsla«, s. $204-233$

6. Jvf. Bomann-Larsen, 1993 og Goksøyr, 1996.

7. Jvf. Skjerk, 1996 og Nielsen, Boe, 1996.

8. Jvf. Mangan, 1995, s. 1.

9. Årsskrift for Gymnastikhøjskolen i Ollerup, 1924, s. 78.

10. Jvf. Rask Nielsen, Niels Bukh, Kbh., 1950, s. 162.

11. Årsskrift, op.cit., 1933, s. 120.

12. Jvf. Fyns Tidende, 24/8, 1934.

13. F.eks. i Berlingske Aftenavis, 28/10, 1933 og Fyns Venstreblad, 29/10, 1933.

14. Svendborg Avis, 13/3, 1934.

15. Jvf. Rask Nielsen, op.cit., s. 162.

16. Roskilde Tidende, Fyns Venstreblad og Randers Amtstidende, 24/7, 1935. Også venstreavisen Vendsyssel Tidende bragte pressemeddelelsen.

17. Dansk Idræt, nr. 11, 1935, s. 126.

18. Jvf. Trommer, 1969, s. 305.

19. Fyns Tidende, 24/8, 1934.

20. Den følgende gennemgang af stævnets program bygger, når intet andet er nævnt, på det officielle program »Landsstævnet i Ollerup 1935, Nordisk olympiade«, Svendborg, 1935.

21. Jvf. Rask Nielsen, ibid.

22. Jeg har ikke undersøgt reaktionerne i de andre nordiske lande.

23. Dahl, 1942, s. 97.

24. BT, 26/7, 1935.

25. Fyns Venstreblad, 5/8, 1934.

26. Jvf. den konservative Jydske Tidende, artiklen »Skarpe ord mod Niels Bukh« om en generalforsamling i Vejle Amts SGI, 21/3, 1935.

27. Fåborg Avis 29/7, 1935.

28. Program for »Udstillingen af kunst under Det store nordiske stævne på Ollerup Gymnastikhøjskole, 25-28. juli, 1935《.

29. Jvf. »En storartet kunstudstilling i Idrætshallen«, Politiken, 27/2, 1935. Venstreavisen Svendborg Avis var dog stærkt sarkastisk overfor Bjerke Petersens surrealistiske malerier, 24/7, 1935.

30. Bukhs private stuer var præget af landskabsmalerier med fysisk arbejdende unge landboere.
31. Ifølge Bukh i Årsskrift op.cit., 1936, s. 98-117.

32. Mors $\varnothing$ Folkeblad, 25/7, 1935.

33. Om Rørdam se Agger 1984, s. 553f. Rørdam brugte under besættelsen sin digtekunst $\mathrm{i}$ den nazistiske agitations tjeneste, jvf. hyldestdigtet til den faldne von Schalburg i Tidsskriftet Danebroge 28/7, 1942, nr. 6.

34. Politiken 26/7, 1935.

35. 26/7, 1935. I filmen om Den nordiske olympiade har den svenske og danske flagkoreografi en central placering. »Det levende dannebrog « dannede skole og blev f.eks. også vist ved landsstævnet i Århus, 1966 og Svendborg, 1994.

36. Om forbindelsen mellem $\mathrm{k} ø \mathrm{n}$ og nationalisme se Harbsmeier, 1986.

37. Jvf. interview i Svendborg Avis 27/7, 1935.

38. Middelfart Socialdemokrat, 29/7, 1935 samt filmen om Landsstævnet.

39. Bukh, Årsskrift, op.cit., 1935, s. 113.

40. Ibid, s. 98-117.

41. Jvf. den konservative Fåborg Avis 29/7, 1935.

42. Politiken-Magasinet, 21/7, 1935.

43. 26/7, 1935.

44. Jydske Tidende ifølge Hanne Lykkes scrapbog (privateje), udateret.

45. Jvf. venstreavisen Mors $\varnothing$ Folkeblad, 27/7, 35.

46. Jvf. Ungdom og Idræt, 18/10, 1935, s. 510.

47. Jvf. f.eks. Politiken, 27/7, 1935.

48. 26/7, 1935.

49. $25 / 7,1935$.

50. Jvf. Hanne Lykkes scrapbog, ibid (udateret).

51. 26/7, 1935.

52. Jvf. Vendsyssel Tidende, Randers Amtstidende, Roskilde Tidende og Fyns Venstreblad, 24/7, 1935.

53. Djurslands Venstreblad, 27/7, 1935.

54. Berlingske Tidende, 27/3, 1935.

55. Karlsson, I, 1984, s. 11-13.

56. Jvf. Svendborg Avis, 27/7, 1935.

57. Jvf. brev til undertegnede fra Ellen Haastrup 6/3, 1995.

58. Jvf. Rask Nielsen, op.cit., s. 162.

59. Jvf. brev fra Nordische Gesellschaft til Bukh af 9/3, 1937 og Bukhs udaterede svar.

60. Socialdemokraten 27. og 29/7, 1935.

61. Jvf. den konservative Århus Stiftstidende, 26/7, 1935, venstreavisen Vestkysten, 27/7, 1935 og Politiken, 28/7, 1935.

62. Af Bukhs pas fremgår det, at han frem til landsstævnet var i Tyskland 3/10 1932, 28/9 1933, 16/10 - 19/10 1933, 4/10 - 16/10 1934, 13/6 - 
17/6 1935 og 28/6 - 2/7 1935. En sammenligning af disse datoer med datoerne for nazisternes rigspartidagene i Nürnberg viser, at Bukh ikke har overværet partidagene før i 1936, jvf. Zentner (m.fl.), 1985, s. 481.

63. Jvf. Thamer, 1992.

64. Om partidagenes »dramaturgi« se Loiperdinger, 1987, s. $61 \mathrm{ff}$.

65. Oprindeligt var der planlagt en særlig teltlejr til hver nation, Fyns Venstreblad, 5/8, 1934.

66. Herunder de olympiske leges tradition fra 1912 med at afholde konkurrencer i male- og digtekunst, jvf. Durry, 1975, s. 205-220.

67. Vendsyssel Tidende 29/7, 1935 og Ålborg Stiftstidende, 28/7, 1935. Sidstnævnte artikel citerer fra en artikel om stævnet i Hamburger Fremdenblatt.

68. Jvf. Politiken, 26/7, 1935.

69. Brev fra Bukh til H.P. Hanssen, 24/6, 1935, Landsarkivet for Sønderjylland.

70. Jvf. Dagens Nyheder, 25/7, 1935.

71. Svendborg Avis, 25/7, 1935.

72. Kristeligt Dagblad, 26/7, 1935.

73. Berlingske Aftenavis, 27/7, 1935.

\section{Litteraturliste}

Agger G., m.fl., Dansk litteraturhistorie, bd. 7, Demokrati og kulturkamp 1901-45, Kbh., 1984.

Bomann-Larsen, T., Den evige sne, en skihistorie om Norge, Oslo, 1993.

Bonde, H., National Identity and the Body, The Nordic Olympiad in Denmark in 1935, Scandinavian Journal of History, 20, 1995, s. 295-313.

Canetti, E., Masse und Macht, Düsseldorf, 1960 (på dansk 1996).

Christiansen, N.F., Socialismen og fædrelandet -Arbejderbevægelsen mellem internationalisme og national stolthed 1871-1940, i: Feldbæk, 1992. s. 573-587.

Dahl, S. (red.), Danmarks kultur ved aar 1940, bd. II, Kbh., 1942.

Durry J., The Fine Arts and the Olympic Games, The International Olympic Academy, Olympia, 1975, s. 205-220.

Ehn, B., m.fl., Försvenskningen af Sverige, Stockholm, 1993.

Feldbæk, O. (red.), Dansk identitetshistorie bd. 3 Folkets Danmark 1848-1940, Kbh., 1992.

Goksøyr, M, m.fl., Winter games, Warm Traditions, Oslo, 1996.
74. BT, 28/7, 1935.

75. Arbejderbladet, 26/7, 1935.

76. BT, 28/7, 1935. Knutzen var medlem af stævnets præsidium. Han blev i 1941 efter pres fra regeringen formand for Dansk-Tysk Forening og efter besættelsen afsat i unåde fra sin stilling i DSB, jvf. Kaarsted, 1991.

77. Jvf. Interview med H. Mortensen

78. Jvf. Hammerich, 1986, kap. 9.

79. Jvf. Danmarksfilmen.

80. I Elias Canettis masseteori (1960) ses tabet af jegbevidsthed til fordel for den kollektive udflydning i det store menneskehav som et positivt kendetegn ved massen, hvorved han på mærkværdig vis i betragtning af sin jødiske baggrund nedtoner faren for ukritisk dyrkelse af den stærke leder.

81. I den tyske völkische ideologi blev sociale klasser og politiske partier anset for »kunstige«, og det repræsentative demokrati afvist til fordel for en »semimystisk elitedyrkelse«. Ikke kun gennem forbindelse til natur og historie, men også i stigende grad til den videnskabeliggjorte racisme, skulle folkets enhed sikres.

Hammerich, P., Lysmageren - en krønike om Poul Henningsen, Kbh., 1986.

Harbsmeier, M., Danmark: Nation, kultur og køn, Stofskifte - Tidsskrift for antropologi, nr. 13, 1986, s. 47-74.

Jørgensen, P., Ro, renlighed, regelmassighed, Dansk Idrats-Forbund og sportens gennembrud ca. 18961918, Kbh., 1997.

Karlsson, I. og Ruth, A., Samhället som teater - Estetik och politik $i$ Tredje riket, Uddevalla, 1984.

Kaarsted, T., Gyldendal og Politikens Danmarkshistorie, bind 13, Kbh., 1991.

Loiperdinger, M., Der Parteitagsfilm »Triumph des Willens « von Leni Riefenstahl, Opladen,

Mangan, J.A. (red.), Tribal Identities, Nationalism, Europe and Sport, London, 1995 (bind 12, nr. 2 af The International Journal of the History of Sport).

Nielsen, N. Boe, Havsvømningens historie, Idratshistorisk Årbog, 1997, 45-54.

Skjerk, O., En svømmepige bliver til, Idratshistorisk Årbog, 1997, s. 55-70.

Thamer, H.U., Verführung und Gewalt, Berlin, 1986.

Thamer, H.-U., Von »der Äesthetisierung der Politik «: Die Nürnberger Reichsparteitage der NSDAP, 
i: Ogan: B. og Weiss, W., Faszination und Gewalt, Nürnberg, 1992.

Trommer, Aa., Oprøret i KU i 1938, i: Hilsen til Hoestrup, Odense, 1969, s. 304-330.
Zentner, C., (m.fl., red.), Das grosse Lexikon des Dritten Reiches, München, 1985. 